Article

\title{
Knoevenagel condensation reaction over acid-base bifunctional MgO/HMCM-22 catalysts
}

\author{
ZHANG Wenfei a , LIANG Jinhua b , LIU Yanqiu a, SUN Shoufei a, REN Xiaoqian ${ }^{\text {a,* }}$, JIANG Min ${ }^{\mathrm{b}}$ \\ a College of Chemistry and Chemical Engineering, Nanjing University of Technology, Nanjing 210009, Jiangsu, China \\ ${ }^{\mathrm{b}}$ College of Biotechnology and Pharmaceutical Engineering, Nanjing University of Technology, Nanjing 210009, Jiangsu, China
}

\section{A R T I C L E I N F O}

Article history:

Received 30 September 2012

Accepted 26 December 2012

Published 20 March 2013

\section{Keywords:}

MCM-22 zeolite

Magnesium oxide

Impregnation

Acid-base bifunction

Knoevenagel condensation reaction

\begin{abstract}
A B S T R A C T
MgO/HMCM-22 catalysts were prepared by impregnation and characterized by X-ray diffraction, $\mathrm{N}_{2}$ physical adsorption-desorption, scanning electron microscopy, Fourier-transform infrared spectroscopy, temperature-programmed desorption of $\mathrm{NH}_{3}$, and temperature-programmed desorption of $\mathrm{CO}_{2}$. The results show that there were no significant structural changes in the MCM-22 zeolite after modification. Increasing the $\mathrm{MgO}$ loading increased the strength and content of the base, whereas the strength of the strong acid decreased significantly and the amount of weak acidic sites increased slightly. Knoevenagel condensation reactions were carried out as the probe reactions over the catalysts. Both acidic sites and basic sites significantly promoted the reaction. The conversion of benzaldehyde reached $92.6 \%$ under the optimal conditions. The catalytic performance of MgO/HMCM-22 and MgO/NaMCM-22 was better than that of HMCM-22 and MgO. The MgO/HMCM-22 catalysts gave good catalytic performance for Knoevenagel condensation reactions and exhibited obvious acid-base synergetic effects.
\end{abstract}

(C) 2013, Dalian Institute of Chemical Physics, Chinese Academy of Sciences. Published by Elsevier B.V. All rights reserved.

\section{Introduction}

The Knoevenagel condensation reaction is one of the most useful routes for the synthesis of $\mathrm{C}=\mathrm{C}$ bonds [1], and has been used to prepare coumarin and its derivatives [2] and cinnamic acid [3]. The reaction has found wide applications in organic synthesis. It is mainly performed using a carbonyl compound and an active methylene compound in the presence of a basic catalyst. Since Hein et al. [4] reported that the Knoevenagel condensation reaction was catalyzed cooperatively by acidic and basic active sites, acid-base bifunctional catalysts with good dispersion of active centers and high catalytic activities have received much attention [5-9]. Climent et al. [10] hold that the catalytic activities of catalysts with suitable acid-base pairs are better than those of strong solid basic catalysts. Peng et al. [11] prepared a controllable acid-base bifunctionalized catalyst via in-situ cleavage of sulfonamide bonds. The catalyst exhibited good performances in catalyzing Knoevenagel condensation reactions. Postole et al. [12] studied the reaction over acid-base bifunctional nanocrystalline $\mathrm{Ce}_{x} \mathrm{Zr}_{1-x} \mathrm{O}_{2}$ solid solutions and further demonstrated that the Knoevenagel condensation reaction was cooperatively catalyzed by acidic and basic sites.

Alkaline-earth-metal oxides are good solid basic catalysts. The alkalinities of the catalyst are enhanced by modification with alkaline-earth-metal oxides and these catalysts have good catalytic activities and selectivities [13,14]. MCM-22 molecular sieves, which have a high $\mathrm{Si} / \mathrm{Al}$ ratio, have good thermal and hydrothermal stabilities, adjustable acidity, a high specific surface area, and a supercage structure [15-17]. They have the potential for use in a broad range of industrial applications. In

\footnotetext{
* Corresponding author. Tel: +86-25-83587167; E-mail: xqren@njut.edu.cn This work was supported by the National Basic Research Program of China (973 Program, 2009CB724701), the National High Technology Research and Development Program of China (863 Program, 2011AA02A203), and the Jiangsu Planned Projects for Postdoctoral Research Funds (1001016C). DOI: 10.1016/S1872-2067(11)60493-2 | http://www.sciencedirect.com/science/journal/18722067 | Chin. J. Catal., Vol. 34, No. 3, March 2013
} 
the present work, MgO is used to adjust the acidity and basicity of the catalyst, and an acid-base bifunctional catalyst, MgO/HMCM-22, is prepared by impregnation. The effects of the reaction conditions on Knoevenagel condensation reactions are also investigated.

\section{Experimental}

\subsection{Catalyst preparation}

Na-MCM-22 zeolites with $\mathrm{Si} / \mathrm{Al}=30$ were synthesized using a previously reported method [18]. The ammonium form was prepared by ion-exchange for $2 \mathrm{~h}$ at $80{ }^{\circ} \mathrm{C}$ with a $1.0 \mathrm{~mol} / \mathrm{L}$ $\mathrm{NH}_{4} \mathrm{NO}_{3}$ solution. The resulting material was filtered, washed, and dried. The $\mathrm{NH}_{4}-\mathrm{MCM}-22$ zeolite was then calcined at $550{ }^{\circ} \mathrm{C}$ for $5 \mathrm{~h}$. The above procedures were repeated three times and the HMCM-22 zeolite was obtained.

HMCM-22 was impregnated with an aqueous solution of $\mathrm{Mg}\left(\mathrm{NO}_{3}\right)_{2}$ and dried with stirring at $80{ }^{\circ} \mathrm{C}$, further dried for $4 \mathrm{~h}$ at $110{ }^{\circ} \mathrm{C}$, and calcined at $550{ }^{\circ} \mathrm{C}$ for $5 \mathrm{~h}$. MgO/HMCM-22 catalysts were obtained. The catalysts MgO/NaMCM-22 and $\mathrm{CaO} / \mathrm{HMCM}-22$ were also prepared for comparison.

\subsection{Catalyst characterization}

X-ray diffraction (XRD) patterns were obtained on a Bruker D8 ADVANCE powder diffractometer, using a $\mathrm{Cu} K_{\alpha}$ radiation source at $40 \mathrm{kV}$ and $40 \mathrm{~mA}$, in the $2 \theta$ range $5^{\circ}-80^{\circ}$ at a scanning speed of $5^{\circ} / \mathrm{min}$. $\mathrm{N}_{2}$ physical adsorption-desorption measurements were carried out on a Chembet-3000 instrument. Before the measurements, the catalysts were placed in a vacuum for 4 $\mathrm{h}$ at $350{ }^{\circ} \mathrm{C}$. The morphologies of the catalysts were observed by scanning electron microscopy (SEM), using QUANTA200 instruments, after each treatment. Fourier-transform infrared (FT-IR) spectra were obtained using a Nexus 870 FTIR spectrometer. Samples were mixed and ground with $\mathrm{KBr}$ for measurements in the range $4000-400 \mathrm{~cm}^{-1}$, with a resolution of 4 $\mathrm{cm}^{-1}$. The acidities and basicities of the catalysts were measured by $\mathrm{NH}_{3}$ and $\mathrm{CO}_{2}$ temperature-programmed desorption $\left(\mathrm{NH}_{3}\right.$-TPD and $\mathrm{CO}_{2}$-TPD), respectively, using an Autochem 2910 instrument connected to a thermal conductivity detector.

\subsection{Knoevenagel condensation reaction}

The Knoevenagel condensation reaction of benzaldehyde and ethyl cyanoacetate was carried out in a 50-ml three-necked flask attached to a reflux condenser. In a typical run, benzaldehyde (50.0 mmol), ethyl cyanoacetate, and catalyst (catalyst $/$ reactants $=0.03$, mass fraction) were added to the reaction mixture, and ethanol $(10.0 \mathrm{ml})$ was mixed in the reactor as the solvent. The reaction was carried out at $80^{\circ} \mathrm{C}$ (or another temperature, as discussed later) for the required time. The conversion of benzaldehyde was determined using a gas chromatograph (SP-6800A) equipped with a capillary column and a flame ionization detector.

\section{Results and discussion}

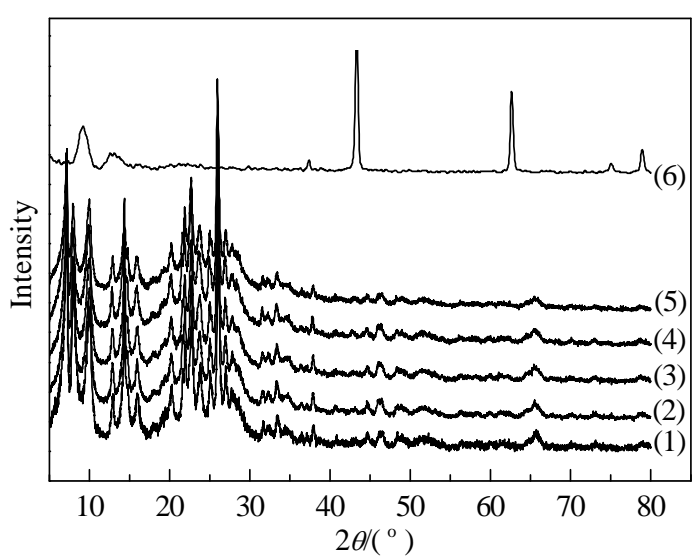

Fig. 1. XRD patterns of HMCM-22 samples with different MgO loadings. (1) HMCM-22; (2) 3\%MgO/HMCM-22; (3) 5\%MgO/HMCM-22; (4) $8 \%$ MgO/HMCM-22; (5) 10\%MgO/HMCM-22; (6) MgO.

\subsection{Catalyst characterization results}

\subsection{1. $X R D$}

The XRD patterns of the catalysts (Fig. 1) show no significant structural changes in MCM-22 after MgO modification. The XRD pattern of MCM-22 shows almost the same features as those described in [19]. Peaks arising from MgO are not observed, because MgO is highly dispersed. However, the crystallinity of the modified MCM-22 decreases with increasing MgO loading. This reduction indicates that excessive $\mathrm{MgO}$ could block the pores of MCM-22 [20].

The data in Table 1 show that the specific surface areas, micropore areas, and pore volumes of the catalysts decrease obviously with increasing MgO loading. These characterization results also imply that a high content of $\mathrm{MgO}$ would cause partial blockage of the pore system of MCM-22. This is in agreement with the SEM images (Fig. 2), which reveal no aggregation on the MCM-22 surface.

\section{Table 1}

Specific surface areas and pore volumes of MgO/HMCM-22 catalyst samples with different MgO loading.

\begin{tabular}{lcccc}
\hline Sample & $A_{\text {BET }} /\left(\mathrm{m}^{2} / \mathrm{g}\right)$ & $V_{\mathrm{T}} /\left(\mathrm{cm}^{3} / \mathrm{g}\right)$ & $A_{\mathrm{M}} /\left(\mathrm{m}^{2} / \mathrm{g}\right)$ & $V_{\mathrm{M}} /\left(\mathrm{cm}^{3} / \mathrm{g}\right)$ \\
\hline HMCM-22 & 543.0 & 1.81 & 439.4 & 1.13 \\
3\%MgO/HMCM-22 & 475.6 & 1.79 & 382.2 & 1.02 \\
5\%MgO/HMCM-22 & 431.4 & 1.46 & 347.1 & 0.71 \\
8\%Mg0/HMCM-22 & 393.2 & 1.26 & 322.8 & 0.58 \\
10\%Mg0/HMCM-22 & 377.0 & 1.13 & 306.0 & 0.51 \\
\hline
\end{tabular}

ABET-BET surface area; $V_{T}-$ Total pore volume; $A_{M}-$ Micropore area; $V_{\mathrm{M}}-$ Micropore volume.

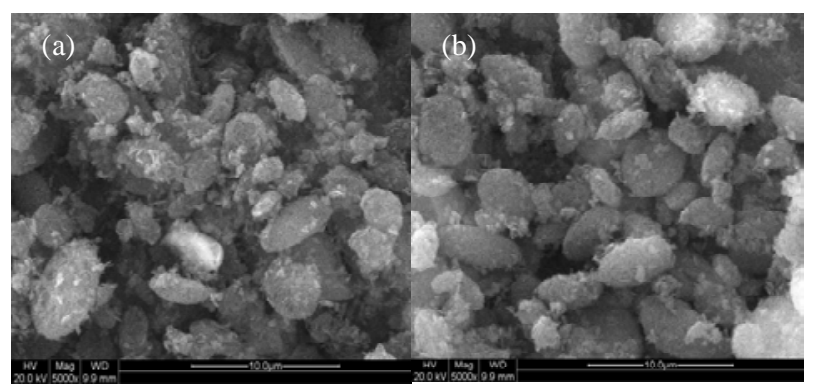

Fig. 2. SEM images of catalysts. (a) HMCM-22; (b) 8\%MgO/HMCM-22. 


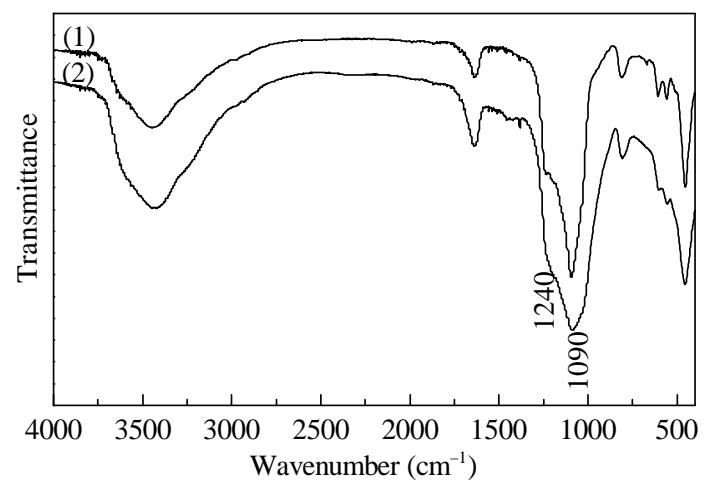

Fig. 3. FT-IR spectra of catalyst HMCM-22 (1) and 8\%MgO/HMCM-22 (2).

\subsection{2. $\quad F T-I R$}

Figure 3 shows the FT-IR spectra of the HMCM-22 and MgO/HMCM-22 catalysts. The structure of MCM-22 after MgO modification is retained. The peaks at 1090 and $1240 \mathrm{~cm}^{-1}$ arise from the asymmetric stretching vibration of a $\mathrm{TO}_{4}$ tetrahedron. Slight decreases in the intensities of these bands are observed after modification as a result of $\mathrm{MgO}$ interacting with the framework of the MCM-22 molecular sieves [21]. The symmetric stretching vibration of the $\mathrm{TO}_{4}$ tetrahedron is found at $804 \mathrm{~cm}^{-1}$ and the peak at $457 \mathrm{~cm}^{-1}$ is linked to the bending vibration of T-0. The bands at 559 and $607 \mathrm{~cm}^{-1}$ are attributed to the dual-ring vibration of the tetrahedral framework [22]. The region with wavenumbers less than $1250 \mathrm{~cm}^{-1}$ is called the framework region [23]. The peak at $1640 \mathrm{~cm}^{-1}$ is the bending mode of water molecules [24].

\subsection{3. $\mathrm{CO}_{2}-\mathrm{TPD}$ and $\mathrm{NH}_{3}-\mathrm{TPD}$}

The $\mathrm{CO}_{2}$-TPD and $\mathrm{NH}_{3}$-TPD profiles of the MgO/HMCM-22
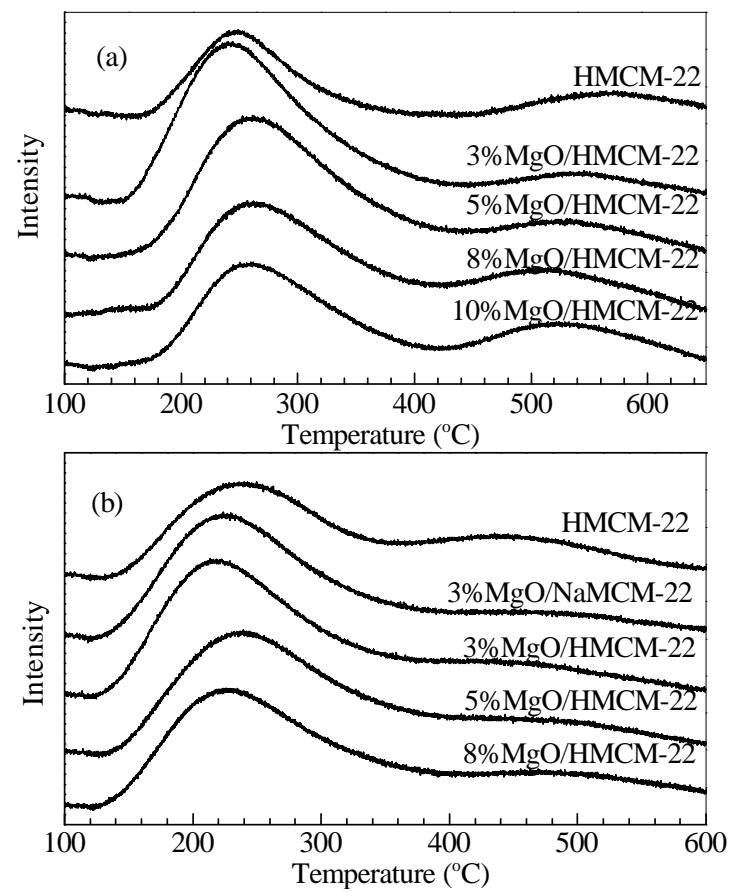

Fig. 4. $\mathrm{CO}_{2}$-TPD profiles (a) and $\mathrm{NH}_{3}$-TPD profiles (b) of HMCM-22 and MgO/HMCM-22 catalyst samples. catalysts are shown in Fig. 4. The two desorption peaks represent weak and strong basic sites or weak and strong acidic sites, respectively. Increasing the MgO loading the strength and content of bases increase obviously. Si-O-Mg is formed after modification. Low-coordinated $\mathrm{O}^{-}$ions [25] can exhibit higher basicity. Obviously decreases the strength and content of strong acids; this is a result of $\mathrm{MgO}$ interacting with acidic sites [26]. The amount of weak acidic sites increases slightly, and this is ascribed to additional acidic sites after $\mathrm{MgO}$ modification because $\mathrm{H}^{+}$ions of the hydroxide groups in the zeolite interact with $\mathrm{MgO}$ to form $\mathrm{Mg}(\mathrm{OH})^{+}$[27]. As mentioned above, acidic and basic sites exist simultaneously on the catalysts.

\subsection{Catalytic performance}

\subsubsection{Effects of MgO loading}

The effects of MgO loading on the catalytic activity are shown in Table 2. The highest conversion is observed over the MgO/HMCM-22 catalyst with $8.0 \%$ MgO loading. The conversions only reach $84.4 \%$ and $6.6 \%$ over $\mathrm{MgO} / \mathrm{NaMCM}-22$ and HMCM-22, respectively. Interestingly, the combination of a functional HMCM-22 zeolite with MgO resulted in a higher conversion than for $\mathrm{MgO}$ alone; $92.6 \%$ versus $72.5 \%$ after $2 \mathrm{~h}$. This demonstrates that the introduction of MCM-22 molecular sieves can promote the dispersion of MgO. In addition, acidic sites can be introduced to facilitate the Knoevenagel condensation reaction together with basic sites. From Table 2, it can be seen that the conversion of benzaldehyde first increases with increasing MgO content, but decreases when the content of $\mathrm{MgO}$ is more than $8.0 \%$. This decrease could be caused by partial blockage of the MCM-22 pore system when the content of $\mathrm{MgO}$ is high, leading to a severe decrease in the surface area, micropore area, and pore volume [28], as shown in Table 1.

\subsubsection{Effects of reaction conditions}

To check the effects of reaction time on the Knoevenagel condensation reaction, the reaction was carried out over $8 \% \mathrm{MgO} / \mathrm{HMCM}-22$ at $80{ }^{\circ} \mathrm{C}$ for different reaction times, ranging from 1 to $6 \mathrm{~h}$, as shown in Fig. 5(a). It was found that in the first $2 \mathrm{~h}$ of the reaction period, the conversion increases linearly and reaches $92.6 \%$, because the reaction is kinetically controlled. The conversion levels off with further increases in the reaction time.

The effects of the benzaldehyde/ethyl cyanoacetate molar ratio on the Knoevenagel condensation reaction are shown in Fig. 5(b). Little change is found at molar ratios below 1 . The

Table 2

Effects of different $\mathrm{MgO}$ loadings on catalytic activity.

\begin{tabular}{lc}
\hline Sample & Conversion (\%) \\
\hline $\mathrm{MgO}^{\mathrm{a}}$ & 72.5 \\
$\mathrm{HMCM}-22$ & 6.6 \\
8\%MgO/NaMCM-22 & 84.4 \\
3\%MgO/HMCM-22 & 69.7 \\
5\%MgO/HMCM-22 & 84.2 \\
8\%MgO/HMCM-22 & 92.6 \\
10\%MgO/HMCM-22 & 88.6
\end{tabular}

Reaction conditions: $80^{\circ} \mathrm{C}, 2 \mathrm{~h}, n$ (benzaldehyde) $/ n$ (ethyl cyanoacetate) $=1, m($ catalyst $) / m($ reactant $)=0.03$. 


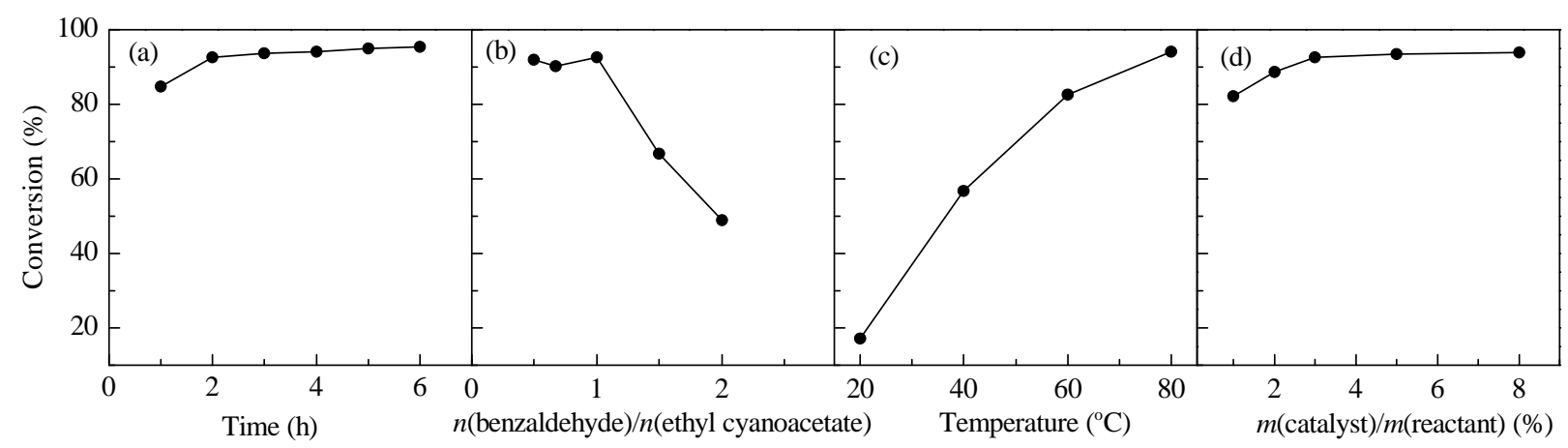

Fig. 5. Effects of reaction time (a), $n$ (benzaldehyde) $/ n$ (ethyl cyanoacetate) (b), temperature (c), $m$ (catalyst) $/ m$ (reactant) (d) on the Knoevenagel condensation reaction. Reaction conditions: (a) $80{ }^{\circ} \mathrm{C}, n$ (benzaldehyde) $/ n$ (ethyl cyanoacetate) $=1, m$ (catalyst) $/ m\left(\right.$ reactant) $=0.03 ;(b) 80{ }^{\circ} \mathrm{C}, 2 \mathrm{~h}$, $m$ (catalyst) $/ m($ reactant $)=0.03 ;$ (c) $2 \mathrm{~h}, n$ (benzaldehyde) $/ n$ (ethyl cyanoacetate) $=1, m($ catalyst $) / m($ reactant $)=0.03 ;(\mathrm{d}) 80{ }^{\circ} \mathrm{C}, 2 \mathrm{~h}$, $n$ (benzaldehyde $) / n$ (ethyl cyanoacetate $)=1$.

maximum conversion is obtained for a 1:1 molar ratio, with $92.6 \%$ conversion of benzaldehyde. However, the conversion drops with further increasing in the molar ratio because excess benzaldehyde blocks some of the available active centers [21].

To optimize the reaction temperature to obtain maximum conversion, the Knoevenagel condensation reaction was carried out at different temperatures, ranging from 20 to $80^{\circ} \mathrm{C}$, for $2 \mathrm{~h}$. From Fig. 5(c), it can be seen that the conversion increases linearly up to $80^{\circ} \mathrm{C}$. At this temperature, ethanol can reflux fully to accelerate the reaction. Moreover, the carbanion intermediates generated in the reaction are stabilized by solvent molecules, promoting the reaction [29].

The effects of catalyst amount on the Knoevenagel condensation reaction were studied by varying the amount of catalyst under the optimized reaction conditions. As shown in Fig. 5(d), increasing the amount of catalyst to $3.0 \%$ increases the conversion to $92.6 \%$. The enhancement of the conversion can be attributed to an increase in the number of catalytically active sites available for this reaction. The conversion remains almost steady for catalyst amounts above $3.0 \%$.

\subsection{Different Knoevenagel condensation over MgO/HMCM-22 and CaO/HMCM-22 catalysts}

Because of its good catalytic activity in the reaction of benzaldehyde with ethyl cyanoacetate, the Knoevenagel condensa-

\section{Table 3}

Different Knoevenagel condensation reactions over MgO/HMCM-22 and $\mathrm{CaO} / \mathrm{HMCM}-22$ catalysts.

\begin{tabular}{lccc}
\hline \multirow{2}{*}{ Reactant 1} & \multirow{2}{*}{ Reactant 2 } & \multicolumn{2}{c}{ Conversion (\%) } \\
\cline { 3 - 4 } & & $8 \% \mathrm{MgO} / \mathrm{HMCM}-22$ & $5 \% \mathrm{CaO} / \mathrm{HMCM}-22$ \\
\hline & $\mathrm{CNCH}_{2} \mathrm{COOEt}$ & 92.6 & 78.2 \\
& $\mathrm{CNCH}_{2} \mathrm{CN}$ & 96.4 & 97.7 \\
& & 96.2 & 98.2 \\
& $\mathrm{CNCH}_{2} \mathrm{COOEt}$ & 98.0 & 98.2
\end{tabular}

Reaction conditions: $80{ }^{\circ} \mathrm{C}, 2 \mathrm{~h}, n($ reactant 1$) / n($ reactant 2$)=1$, $m$ (catalyst $) / m$ (reactant $)=0.03$. tion reactions of different active methylene compounds and aldehydes were carried out over the acid-base bifunctional catalyst MgO/HMCM-22, as shown in Table 3. The conversions of aldehydes are all above $92.5 \%$. Malononitrile is found to be a better reagent than ethyl cyanoacetate, because of its better electron-withdrawing ability. The catalytic activity of CaO/HMCM-22 was also investigated and gave good results. The basic sites, as well as the acidic sites, play positive roles in promoting Knoevenagel condensation reactions. The acid-base bifunctional MgO/HMCM-22 and CaO/HMCM-22 catalysts, i.e., modified by alkaline-earth-metal oxides ( $\mathrm{MgO}, \mathrm{CaO})$, are good catalysts for Knoevenagel condensation reactions.

Corma [30] reported acid-base cooperation for the Knoevenagel condensation reactions of carbonyl compounds with active methylenes via an ion-pair mechanism. According to the results of our experiments and characterizations, MgO/HMCM-22 and CaO/HMCM-22 catalysts exhibit obvious acid-base synergetic effects in the Knoevenagel condensation reaction. A possible mechanism of the Knoevenagel condensation reaction of a carbonyl compound with an active methylene is shown in Scheme 1. Basic sites abstract a proton from the methylene carbon of ethyl cyanoacetate, forming a carbanion. The carbonyl of the aldehyde is activated by acidic sites and a carbocation is generated. A dehydration reaction occurs by the

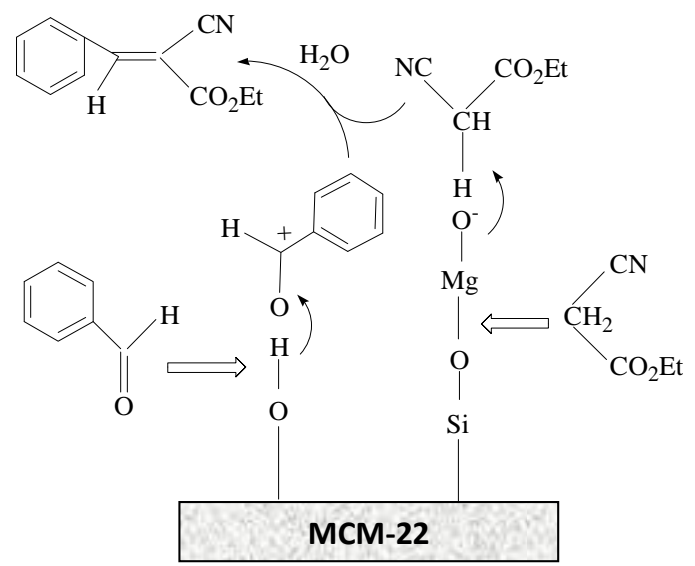

Scheme 1. Possible mechanism of Knoevenagel condensation over MgO/HMCM-22. 
Table 4

Reusability of 8\%MgO/HMCM-22 and 5\%CaO/HMCM-22.

\begin{tabular}{ccc}
\hline \multirow{2}{*}{ Run } & \multicolumn{2}{c}{ Conversion (\%) } \\
\cline { 2 - 3 } & $8 \%$ Mg0/HMCM-22 & $5 \%$ CaO/HMCM-22 \\
\hline 1 & 92.6 & 78.2 \\
2 & 81.7 & 65.7 \\
3 & 72.5 & 57.9 \\
4 & 70.8 & 56.7 \\
\hline
\end{tabular}

Reaction conditions: $80^{\circ} \mathrm{C}, 2 \mathrm{~h}, n$ (benzaldehyde) $/ n$ (ethyl cyanoacetate) $=1, m$ (catalyst $) / m$ (reactant $)=0.03$.

carbanion attacking the carbocation. Subsequent elimination of water results in formation of the products.

\subsection{Catalyst reusability}

As it is very convenient to recover the catalyst at the end of a reaction and recharge it for the next run, the MgO/HMCM-22 and $\mathrm{CaO} / \mathrm{HMCM}-22$ catalysts were recycled by filtering, washing, and drying, without any regeneration steps. The Knoevenagel condensation reaction of benzaldehyde with ethyl cyanoacetate was investigated over these catalysts. The results are listed in Table 4 . The catalytic activity was stable after the third reaction run. The results indicate that there is a decrease in the activity after each use. This may be the result of deactivation of active centers resulting from complexation with both starting materials and products, or of microscopic changes in the structure of the catalyst [31].

\section{Conclusions}

Acid-base bifunctional MgO/HMCM-22 and CaO/HMCM-22 catalysts were prepared using alkaline-earth-metal oxides (MgO, CaO), characterized, and used as efficient catalysts for Knoevenagel condensation reactions. The basicities of the catalysts increase when basic sites are introduced onto HMCM-22.
Acidic sites and basic sites are both significant for this reaction. The basic sites cooperate with the acidic sites, promoting the reaction. The present results suggest that these catalysts have acid-base synergetic effects on the Knoevenagel condensation reactions of carbonyl compounds with active methylenes. The advantages of this method are mild reaction conditions, a simple procedure, and a short reaction time. The conversions were all above $92.5 \%$ under the optimal conditions.

\section{References}

[1] Zhang X F, Lai E S M, Martin-Aranda R, Yeung K L. Appl Catal A, 2004, 261: 109

[2] Bigi F, Chesini L, Maggi R, Sartori G. J Org Chem, 1999, 64: 1033

[3] Parida K M, Rath D. J Mol Catal A, 2009, 310: 93

[4] Hein R W, Astle M J, Shelton R J.J Org Chem, 1961, 26: 4874

[5] Lan D X, Lin D, Zhao H M, Ma L, Chun Y. Chin J Catal (蓝冬雪, 林丹, 赵会民，马丽，淳远. 催化学报), 2011, 32: 1214

[6] Shao Y Q, Guan J Q Wu S J, Liu H, Liu B, Kan Q B. Microporous Mesoporous Mater, 2010, 128: 120

[7] Macario A, Giordano G, Onida B, Cocina D, Tagarelli A, Giuffrè A M. Appl Catal A, 2010, 378: 160

[8] Vermoortele F, Ameloot R, Vimont A, Serre C, Vos D D. Chem Commun, 2011, 47: 1521

[9] Hruby S L, Shanks B H.J Catal, 2009, 263: 181

[10] Climent M J, Corma A, Iborra S, Velty A. J Mol Catal A, 2002, 182-183: 327

[11] Peng Y, Wang J Y, Long J, Liu G H. Catal Commun, 2011, 15: 10

[12] Postole G, Chowdhury B, Karmakar B, Pinki K, Banerji J, Auroux A.J Catal, 2010, 269: 110

[13] Keita I, Nao M, Takayuki T, Masato M. Catal Lett, 2011, 141: 877

[14] Wang T, Wu G J, Guan N J, Li L D. Microporous Mesoporous Mater, 2012, 148: 184

[15] Yu Zh W, Wang Q, Chen L, Deng F. Chin J Catal (喻志武, 王强, 陈 雷, 邓风. 催化学报), 2012, 33: 129

[16] Chu N B, Wang J Q, Zhang Y, Yang J H, Lu J M, Yin D H. Chem Mater, 2010, 22: 2757

[17] Laforge S, Martin D, Guisnet M. Microporous Mesoporous Mater,

\section{Graphical Abstract}

Chin. J. Catal., 2013, 34: 559-566 doi: 10.1016/S1872-2067(11)60493-2

Knoevenagel condensation reaction over acid-base bifunctional MgO/HMCM-22 catalysts

ZHANG Wenfei, LIANG Jinhua, LIU Yanqiu, SUN Shoufei, REN Xiaoqian*, JIANG Min

Nanjing University of Technology

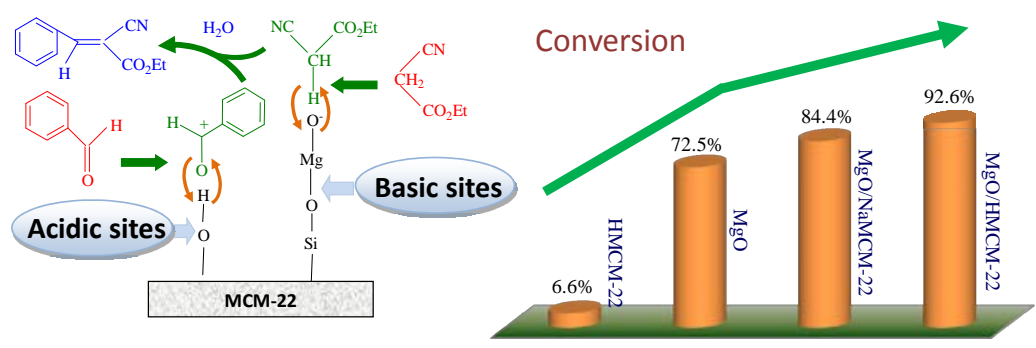

The possible mechanism of acid-base bifunctional catalyst MgO/HMCM-22 for the Knoevenagel condensation reaction was presented. The results show that the catalyst MgO/HMCM-22 exhibited obvious acid-base synergetic effects with good catalytic performance for Knoevenagel condensation reactions. 
2004, 67: 235

[18] Wu Y J, Ren X Q, Lu Y D, Wang J. Microporous Mesoporous Mater, 2008, 112: 138

[19] Shang Y C, Yang P P, Jia M J, Zhang W X, Wu T H. Catal Commun, 2008, 9: 907

[20] Shu Y Y, Ma D, Xu L Y, Xu Y D, Bao X H. Catal Lett, 2000, 70: 67

[21] Jain D, Khatri C, Rani A. Fuel Process Technol, 2010, 91: 1015

[22] Corma A, Corell C, Fornés V, Kolodziejski W, Pérez-Pariente J. Zeolite, 1995, 15: 576

[23] Kumara G S, Saravanamurugan S, Hartmann M, Palanichamy M, Murugesan V.J Mol Catal A, 2007, 272: 38

[24] Liu Z Y, Zhu Z B, Wang R Y, Zhu X D. Chin J Catal (刘子玉, 朱子涁,
王仁远, 朱学栋. 催化学报), 2008, 29: 928

[25] Pappas G S, Liatsi P, Kartsonakis I A, Danilidis I, Kordas G. J Non-Cryst Solids, 2008, 354: 755

[26] Sakthivel A, Komura K, Huang S J, Wu P H, Liu S B, Sasaki Y, Sugi Y. Ind Eng Chem Res, 2010, 49: 65

[27] Xu Q L, Li T C, Yan Y J. J Fuel Chem Technol, 2008, 36: 181

[28] Xue B, Li Y X, Deng L J. Catal Commun, 2009, 10: 1609

[29] Rodriguez I, Sastre G, Corma A, Iborra S. J Catal, 1999, 183: 14

[30] Corma A, Fornés V, Martín-Aranda R M, García H, Primo J. Appl Catal, 1990, 59: 237

[31] Gupta R, Gupta M, Paul S, Gupta R. Bull Korean Chem Soc, 2009, 30: 2419

\title{
酸碱双功能MgO/HMCM-22催化剂上Knoevenagel缩合反应
}

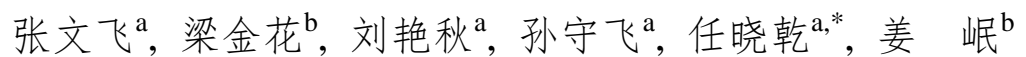 \\ a南京工业大学化学化工学院, 江苏南京 210009 \\ b南京工业大学生物与制药工程学院, 江苏南京 210009
}

\begin{abstract}
摘要: 采用浸渍法制备了一系列 $\mathrm{MgO}$ 改性催化剂 $\mathrm{MgO} / \mathrm{HMCM}-22$, 利用X射线衍射、 $\mathrm{N}_{2}$ 物理吸附-脱附、扫描电镜、傅里叶变换 红外光谱、 $\mathrm{NH}_{3}$ 及 $\mathrm{CO}_{2}$ 程序升温脱附等技术对所制催化剂进行了表征. 结果表明, MgO改性后MCM-22分子篮仍保持原有的结构; 随着 $\mathrm{MgO}$ 负载量的增加, 催化剂的碱强度和碱含量显著增加, 而强酸含量明显减少, 弱酸酸位有所增加. 以Knoevenagel缩合为 探针反应，考察了所制催化剂的性能. 在优化的反应条件下， MgO/HMCM-22 上苯甲醛转化率高达 $92.6 \%$. 催化剂 MgO/HMCM-22和MgO/NaMCM-22的催化性能明显优于HMCM-22和MgO. 酸中心和碱中心均对该缩合反应起着重要的促进作 用. MgO/HMCM-22对Knoevenagel缩合反应显示出较高的催化活性, 体现出明显的酸碱协同催化作用.
\end{abstract}

关键词: MCM-22分子笁; 氧化镁; 浸渍; 酸碱双功能; Knoevenagel缩合反应

收稿日期: 2012-09-30. 接受日期: 2012-11-26. 出版日期: 2013-03-20.

*通讯联系人. 电话: (025)83587167; 电子信箱: xqren@njut.edu.cn

基金来源: 国家重点基础研究发展计划(973计划, 2009CB724701); 国家高技术研究发展计划(863计划, 2011AA02A203); 江苏省 博士后科研资助计划(1001016C).

本文的英文电子版由Elsevier出版社在ScienceDirect上出版(http://www.sciencedirect.com/science/journal/18722067).

\section{1. 前言}

Knoevenagel 缩合反应是含有活泼亚甲基氢的化合 物和羰基化合物的加成消除反应, 它是医药中间体合成 中制备不饱和烯烃的重要方法 ${ }^{[1]}$; 该不饱和烯烃可以进 一步加成合成香豆素及其衍生物 ${ }^{[2]}$ 、肉桂酸 ${ }^{[3]}$ 等, 在有 机合成中有着广泛的应用. 该缩合反应主要通过碱催化 实现. 自 Hein 等 ${ }^{[4]}$ 提出 Knoevenagel 缩合反应为酸碱 协同催化反应以来, 酸碱双功能催化剂以其良好的活性 位分布和高的催化活性引起了广泛的关注 ${ }^{[5 \% 9]}$. Climent 等 ${ }^{[10]}$ 认为, 具有合适酸碱电子对催化剂的活性高于固体 强碱催化剂. Peng 等 ${ }^{[11]}$ 利用磺酰胺的原位分解在载体 表面构筑出匹配的酸碱双活性中心, 对 Knoevenagel 缩 合反应具有较好的催化性能. Postole 等 ${ }^{[12]}$ 采用酸碱双 功能纳米固溶体 $\mathrm{Ce}_{x} \mathrm{Zr}_{1-\mathrm{x}} \mathrm{O}_{2}$ 催化该反应, 其结果进一步 证实了该缩合反应是在酸碱协同催化作用下完成的.

碱土金属氧化物是一种良好的固体碱催化剂, 将它
用于改性催化剂不仅可以增强其碱性, 同时还能提高催 化活性和选择性 ${ }^{[13,14]}$. 作为高硅铝比分子篮, MCM-22 不仅具有高的热稳定性和水热稳定性, 同时还拥有可调 变的酸性、大的比表面积和超笼结构 ${ }^{[15 ~ 17]}$, 因而具有广 泛的工业应用前景. 本文采用 MgO 改性 MCM-22 分子 篮, 通过调变 MCM-22 的酸碱性质, 制备了酸碱双功能 催化剂 MgO/HMCM-22, 并考察了它在不同反应条件下 催化 Knoevenagel 缩合反应的性能.

\section{2. 实验部分}

\section{1. 催化剂的制备}

参照文献[18]合成了硅铝比为 30 的 NaMCM-22 分 子篮, 再与 $\mathrm{NH}_{4} \mathrm{NO}_{3}$ 溶液 $(1.0 \mathrm{~mol} / \mathrm{L})$ 在 $80^{\circ} \mathrm{C}$ 下离子交 换 $2 \mathrm{~h}$, 经过滤, 洗涤, 烘干等操作, 于 $550^{\circ} \mathrm{C}$ 焙烧 $5 \mathrm{~h}$, 重 复以上操作三次, 制得 HMCM-22 分子篎.

将制得的 HMCM-22 分子篮分别浸渍于不同浓度 的 $\mathrm{Mg}\left(\mathrm{NO}_{3}\right)_{2}$ 溶液, 并于 $80^{\circ} \mathrm{C}$ 摚拌蒸干, $110^{\circ} \mathrm{C}$ 干燥 4 
$h$, 再于 $550^{\circ} \mathrm{C}$ 焙烧 $5 \mathrm{~h}$, 制得了不同负载量的 $\mathrm{MgO} / \mathrm{HMCM}-22$ 催化剂. 为了比较还制备了 MgO/NaMCM-22 和 CaO/HMCM-22 催化剂.

\section{2. 催化剂的表征}

采用 Bruker 公司的 D8 ADVANCE 型 X 射线衍射 (XRD) 仪对催化剂进行表征, $\mathrm{Cu}$ 靶 $K_{\alpha}$ 射线源, 管电压 $40 \mathrm{kV}$, 管电流 $40 \mathrm{~mA}$, 扫描范围 $2 \theta=5^{\circ} \sim 80^{\circ}$, 扫描速率 $5 \%$ min. $\mathrm{N}_{2}$ 吸附-脱附法测定样品的比表面积在美国 Quantachrome 公司的 Chembet-3000 型物理吸附仪上进 行, 吸附之前样品先在 $350{ }^{\circ} \mathrm{C}$ 真空干燥 $4 \mathrm{~h}$. 催化剂的 表面形貌在 Philips 公司的 QUANTA200 型扫描电镜 (SEM) 上测试. 催化剂的傅里叶变换红外光谱 (FT-IR) 表征采用 Thermo Nicolet 公司的 Nexus870 型傅里叶红 外光谱仪测试, 测试条件为: $\mathrm{KBr}$ 压片, 波数范围 $4000 \sim 400 \mathrm{~cm}^{-1}$, 分辨率 $4 \mathrm{~cm}^{-1}$. 同时, 采用 Autochem 2910 型程序升温脱附 (TPD) 装置对催化剂进行 $\mathrm{NH}_{3}$-TPD 与 $\mathrm{CO}_{2}-\mathrm{TPD}$ 表征, 以分析其酸碱性, TCD 检 测器.

\section{3. 催化剂的评价}

以苯甲醛和氧基乙酸乙酯的 Knoevenagel 缩合为探 针对催化剂性能进行评价. 将 $50 \mathrm{mmol}$ 的苯甲醛, 50 $\mathrm{mmol}$ 的氰乙酸乙酯及 $10 \mathrm{ml}$ 溶剂乙醇加入装有冷凝管 的 $50 \mathrm{ml}$ 三口烧瓶中, 并加入总反应物质量 3.0\% 的催 化剂, 升至预定温度下反应。考察不同反应条件对 Knoevenagel 缩合反应的影响。反应过程中采用 SP-6800A 型气相色谱仪分析反应液组成并计算苯甲醛 的转化率, 毛细管柱, 火焰离子化检测器, 采用程序升温 法进行检测.

\section{3. 结果与讨论}

\section{1. 催化剂的表征结果}

\subsection{1. 催化剂的结构参数和形貌}

图 1 为一系列 $\mathrm{MgO} / \mathrm{HMCM}-22$ 催化剂的 XRD 谱. 可以看出, 经 $\mathrm{MgO}$ 改性后, 样品仍在 $2 \theta=7.1^{\circ}, 9.5^{\circ}$, $22.7^{\circ}, 26.0^{\circ}$ 左右出现衍射峰, 分别对应于 MCM-22 分子 篎 (100) (hkl), (102), (302), (310) 晶面的特征峰 ${ }^{[19]}$, 表明 MgO 改性并未影响 MCM-22 分子篮原有的骨架结构. 另外, 催化剂并未出现明显的 $\mathrm{MgO}$ 衍射峰, 表明 $\mathrm{MgO}$ 呈高度分散状态; 但改性 MCM-22 的结晶度随着 $\mathrm{MgO}$ 负载量的增加而降低, 这是由于引入的 $\mathrm{MgO}$ 填充了部 分 MCM-22 的孔道所致 ${ }^{[20]}$.

表 1 为各催化剂的结构参数. 可以看出, 随着 $\mathrm{MgO}$
负载量的增加, 催化剂的比表面积和总孔孔容以及微孔 面积和微孔孔容均降低, 从而进一步证实了 $\mathrm{MgO}$ 填充 了部分分子笁的孔道, 造成了催化剂比表面积与孔容的 下降.

图 2 为各催化剂的 SEM 照片. 可以看出, $\mathrm{MgO}$ 并 未在催化剂表面产生明显的聚集, 与 XRD 结果一致.

\subsection{2. 催化剂的 FT-IR}

图 3 为各催化剂的 FT-IR 谱. 由图可见, 改性后的 MCM-22 分子篎仍出现原有分子篮的特征吸收峰. 1090 与 $1240 \mathrm{~cm}^{-1}$ 处吸收峰对应分子篮的 T-O-T 四面体的 不对称伸缩振动. $\mathrm{MgO}$ 改性后, 该峰强度有所减弱, 可 能是由于部分 $\mathrm{MgO}$ 与分子篮骨架作用所致 ${ }^{[21]} ; 607$ 与 $559 \mathrm{~cm}^{-1}$ 处吸收峰对应于四面体骨架双环振动 ${ }^{[22] ;} 457$ $\mathrm{cm}^{-1}$ 处吸收峰为 $\mathrm{T}-\mathrm{O}$ 键的弯曲振动; $804 \mathrm{~cm}^{-1}$ 处峰对 应于 $\mathrm{T}-\mathrm{O}-\mathrm{T}$ 四面体的对称伸缩振动. Kumara 等 ${ }^{[23]}$ 认 为, $<1250 \mathrm{~cm}^{-1}$ 吸收峰区域为 “骨架区域”. 而 $1640 \mathrm{~cm}^{-1}$ 处吸收峰为 $\mathrm{H}-\mathrm{O}$ 键的弯曲振动, 即催化剂吸附水的羟 基峰 ${ }^{[24]}$.

\subsection{3. 催化剂的 $\mathrm{CO}_{2}$-TPD 谱和 $\mathrm{NH}_{3}$-TPD 谱}

图 4 为 HMCM-22 和 $\mathrm{MgO} / \mathrm{HMCM}-22$ 催化剂的 $\mathrm{CO}_{2}$-TPD 谱和 $\mathrm{NH}_{3}$-TPD 谱. 图 4(a) 和 (b) 中两个脱附 峰分别对应催化剂的弱碱和强碱中心以及弱酸和强酸 中心. 可以看出, 随着 $\mathrm{MgO}$ 负载量的增加, 催化剂上弱 碱与强碱碱强度和碱量明显增加, 可能是由于形成了 $\mathrm{Si}-\mathrm{O}-\mathrm{Mg}$ 键, 而低配位的 $\mathrm{O}^{-}$的存在 ${ }^{[25]}$, 使得催化剂上弱 碱与强碱碱量明显增加. 然而, 强酸酸强度与酸量明显 降低, 这是由于碱性 $\mathrm{MgO}$ 的产生减弱了分子篮的酸 性 ${ }^{[26]}$; 催化剂上弱酸酸位有所增加, 可能是由于少量的 $\mathrm{MgO}$ 与 $\mathrm{H}^{+}$作用形成的 $\mathrm{MgO}(\mathrm{OH})^{+}$所致 ${ }^{[27]}$. 可见, 改性 后的催化剂上同时存在着一定量的碱中心和酸中心.

\section{2. 催化剂的催化性能}

\subsection{1. $\mathrm{MgO}$ 负载量的影响}

表 2 为 $\mathrm{MgO}$ 负载量对 $\mathrm{MgO} / \mathrm{HMCM}-22$ 催化剂活 性的影响. 可以看出, 当以 HMCM-22 和 $\mathrm{MgO} / \mathrm{NaMCM}-22$ 为催化剂时, 苯甲醛转化率分别只有 $6.6 \%$ 和 $84.4 \%$, 而单独采用 $\mathrm{MgO}$ 为催化剂时, 苯甲酫的 转化率也只有 $72.5 \%$. 可见, MCM-22 分子篮载体的引 入有利于 $\mathrm{MgO}$ 的分散, 从而获得更多的活性位; 同时, MCM-22 分子篮还可提供适量的酸性位, 通过碱中心与 酸中心共同对反应底物的作用促进该反应的进行. 还可 看出, 随着 $\mathrm{MgO}$ 的改性及其负载量的增加, 苯甲醛转化 率显著增加; 至 $8.0 \%$ 时, 苯甲醛转化率达最高; 继续增 
加 $\mathrm{MgO}$ 负载量, 催化活性略有降低. 结合表 1 可知, 可 能是由于过量的 $\mathrm{MgO}$ 填充了 MCM-22 的孔道, 覆盖了 一部分的活性位, 使其比表面积、微孔面积和孔容减 小 ${ }^{[28]}$, 因而催化活性降低.

\subsection{2. 反应条件的影响}

图 5 为以 $8 \% \mathrm{MgO} / \mathrm{HMCM}-22$ 为催化剂时不同反应 条件对 Knoevenagel 缩合反应的影响. 由图 5(a) 可看 出, 随着反应时间的增加, 苯甲醛转化率显著增加, 此阶 段反应主要在动力学控制下发生; 至 $2 \mathrm{~h}$ 时苯甲酫转化 率达到 92.6\%; 然而, 继续延长反应时间, 苯甲醛转化率 变化不大.

图 5(b) 为反应物摩尔比 (苯甲醛/氰乙酸乙酯) 对缩 合反应的影响. 可以看出, 当反应物摩尔比 $<1.0$ 时, 苯甲 醛转化率随着反应物摩尔比的增加而转化率变化不大; 至 1.0 时, 达最高, 为 $92.6 \%$; 继续增大反应物摩尔比, 苯甲醛转化率急剧下降, 可能是由于过量的苯甲醛占据 催化剂的活性位, 使得可利用的活性位减少所致 ${ }^{[21]}$.

图 5(c) 考察了反应温度对 Knoevenagel 缩合反应 的影响. 由图看出, 随着反应温度的升高, 苯甲醛转化率 趋于线性增加; 至 $80^{\circ} \mathrm{C}$ 时达最大. 这是由于该温度与 溶剂乙醇的沸点相近, 乙醇能够充分的冷凝回流, 同时 溶剂乙醇分子可以稳定反应过程中形成的碳负离子中 间体 ${ }^{[29]}$, 从而促进反应的进行.

图 5(d) 为催化剂用量对该缩合反应的影响, 由图可 见, 随着催化剂用量的增加, 催化活性中心增多, 苯甲醛 转化率逐渐增加; 至3.0\%时达 $92.6 \%$. 继续增加催化剂 用量, 苯甲醛转化率变化不大.

\subsection{MgO/HMCM-22 和 CaO/HMCM-22 催化剂上不 同 Knoevenagel 缩合反应}

鉴于 $\mathrm{MgO} / \mathrm{HMCM}-22$ 催化剂对苯甲醛和氰基乙酸 乙酯的缩合反应表现出较高的催化活性, 本文考察了较 佳反应条件下酸碱双功能 MgO/HMCM-22 催化剂对不 同活泼亚甲基化合物和醛的 Knoevenagel 缩合反应的催 化活性, 结果列于表 3. 可以看出, MgO/HMCM-22 在不 同 Knoevenagel 缩合反应中均显示出较高的催化活性, 醛转化率均可达 $92.5 \%$ 以上; 由于丙二腈的吸电子能 力强于氧基乙酸乙酯, 所以其亚甲基氢的活泼性高于㲵
乙酸乙酯, 使得相应醛的转化率较高. 同时, 还考察了 CaO/HMCM-22对Knoevenagel反应的催化活性, 发现该 样品同样表现出较高的催化活性. 可见, 碱中心和酸中 心对该反应有着重要作用; 同时 $\mathrm{MgO}$ 或 $\mathrm{CaO}$ 改性 MCM-22 所制备的酸碱双功能催化剂是 Knoevenagel 缩 合反应较佳的催化剂.

Corma 等 ${ }^{[30]}$ 认为, 羰基化合物与活泼亚甲基氢的 Knoevenagel 缩合反应是根据离子对机理进行的. 结合 以上实验结果可知, 酸碱双功能催化剂 $\mathrm{MgO} / \mathrm{HMCM}-22$ 和 CaO/HMCM-22 在催化活泼亚甲基氢与羰基化合物 的 Knoevenagel 缩合反应时体现出明显的酸碱协同催化 作用, 因此推测其可能的反应机理如图式 1 所示. 首先, 氧基乙酸乙酯的活泼亚甲基氢与催化剂的碱中心作用 下形成碳负离子; 而苯甲醛的羰基被催化剂酸中心活化 并作用形成碳正离子; 碳负离子与碳正离子进一步作用 脱去一分子水形成目标产物.

\section{4. 催化剂的重复使用性}

固体催化剂易于回收, 有利于重复使用. 反应结束 后, 将反应产物过滤分离出催化剂, 用有机溶剂洗涤、过 滤并烘干后, 不经任何再生处理直接进行重复性实验, 反应结果列于表 4. MgO/HMCM-22 和 CaO/HMCM-22 催化剂随着循环次数的增加, 其活性逐渐下降, 至第 4 次时, 活性略有下降并趋于稳定. 这可能是由于活性组 分的流失或催化剂微观结构的变化所致 ${ }^{[31]}$.

\section{4. 结论}

采用碱土金属氧化物 $\mathrm{MgO}$ 或 $\mathrm{CaO}$ 改性 MCM-22 分子篮制备了新型酸碱双功能催化剂 MgO/HMCM-22 和 CaO/HMCM-22, 并用于 Knoevenagel 缩合反应中. 结果表明, 碱土金属氧化物改性后, 催化剂的碱性增强; 所形成的碱中心与催化剂上的酸中心共同对反应底物 作用, 在羰基化合物与活泼亚甲基氢的 Knoevenagel 缩 合反应中体现出明显的酸碱协同催化作用, 促进了 Knoevenagel 缩合反应的进行, 进一步说明了酸中心和 碱中心对该反应的重要性. 同时该方法制备过程简单, 反应条件温和, 反应时间短, 在优化的条件下醛的转化 率均在 $92.5 \%$ 以上. 